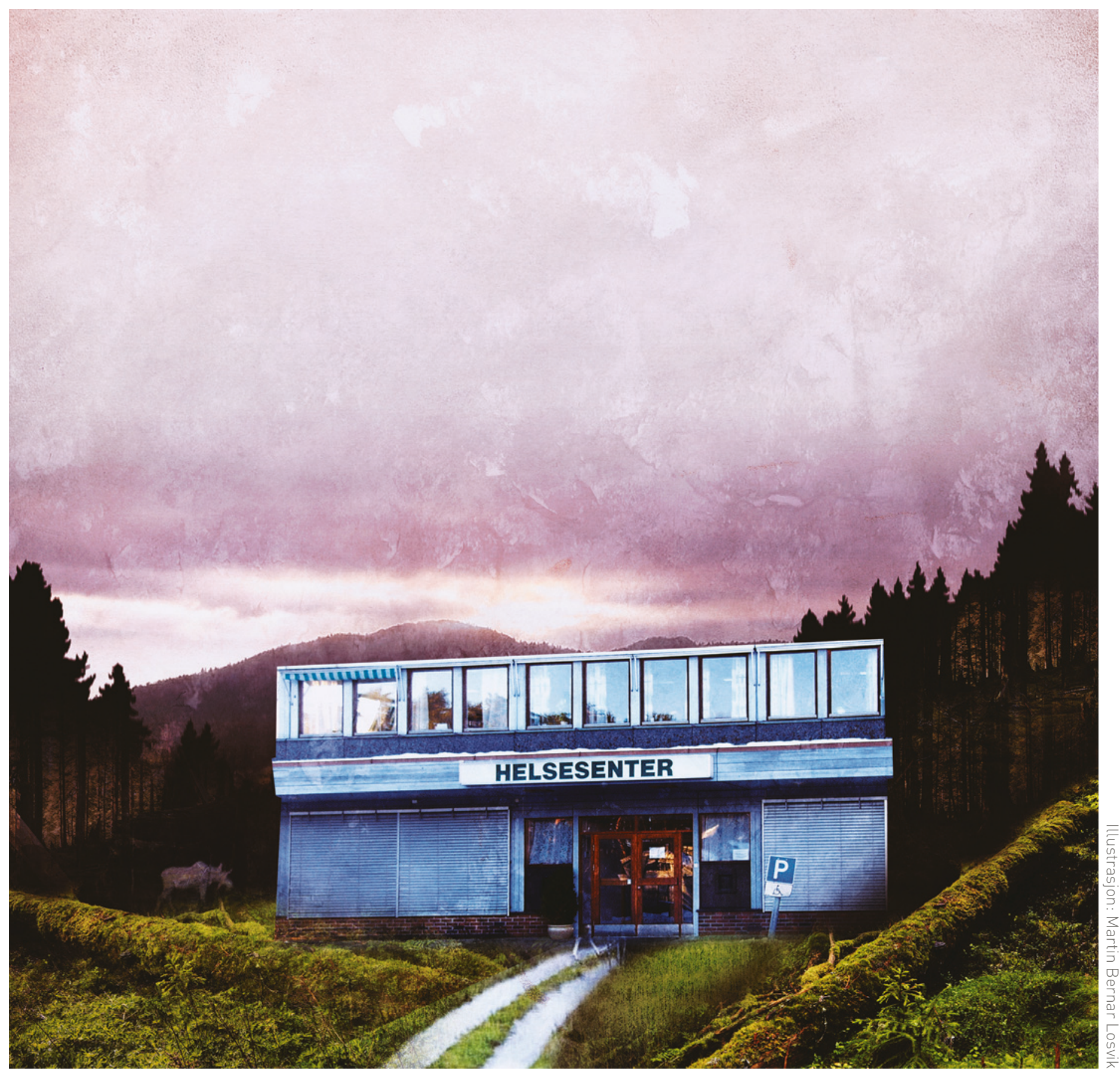

\title{
Våler helsesenter
} Helsestasjon og legesenter for innbyggerne i Våler kommune i Hedmark.
Ansatte: Tre leger, én turnuslege, fem helsesekretærer, to helsesøstre og én jordmor.
Våler kommune har ca. 3900 innbyggere. 